\title{
Peran biofilm bakteri terhadap derajat keparahan rinosinusitis kronis berdasarkan skor Lund-Mackay
}

\author{
Yolazenia*, Bestari Jaka Budiman $^{* *}$, Effy Huriyati"**, Aziz Djamal ${ }^{* * *}$, \\ Rizanda Machmud ${ }^{* * * *}$, Dolly Irfandy ${ }^{* *}$ \\ * Bagian Telinga Hidung Tenggorok - Bedah Kepala Leher \\ Fakultas Kedokteran Universitas Riau \\ ** Bagian Telinga Hidung Tenggorok - Bedah Kepala Leher \\ Fakultas Kedokteran Universitas Andalas \\ ${ }^{* * *}$ Bagian Mikrobiologi Fakultas Kedokteran Universitas Andalas \\ ${ }^{* * * *}$ Bagian Ilmu Kesehatan Masyarakat Fakultas Kedokteran Universitas Andalas \\ Rumah Sakit Umum Pusat Dr. M. Djamil \\ Padang
}

\begin{abstract}
ABSTRAK
Latar belakang: Rinosinusitis kronis (RSK) adalah penyakit inflamasi mukosa hidung dan sinus paranasal yang berlangsung lebih dari 12 minggu. Berbagai kondisi telah dikaitkan dengan patogenesis penyakit ini, seperti infeksi bakteri, jamur, superantigen, dan biofilm. Banyak penelitian telah menunjukkan terdapatnya biofilm bakteri pada pasien dengan RSK. Biofilm bakteri dapat memfasilitasi terjadinya resistensi pada antibiotik. CT Scan sinus paranasal (SPN) merupakan pemeriksaan penunjang pilihan untuk diagnosis radiologik RSK. Lund dan Mackay telah mengembangkan suatu sistem berdasarkan skor dari CT Scan SPN untuk menilai kuantifikasi proses peradangan pada sinus paranasal. Beberapa penelitian menunjukkan bahwa pasien dengan biofilm bakteri memiliki skor Lund-Mackay CT Scan SPN yang lebih tinggi pada saat pra operatif. Tujuan: Penelitian ini bertujuan untuk mengetahui peran biofilm bakteri terhadap derajat keparahan RSK berdasarkan skor Lund-Mackay. Metode: Penelitian ini adalah penelitian cross-sectional dengan jumlah total sampel adalah 48 orang pasien RSK. Sekret hidung diambil menggunakan kapas lidi steril dengan $s w a b$ pada meatus medius lalu dilakukan identifikasi bakteri dan pemeriksaan biofilm dengan tube method. Skor Lund-Mackay dihitung dari CT Scan SPN potongan koronal. Data dianalisis dengan uji Fisher. Hasil: Proporsi pasien RSK dengan skor Lund-Mackay yang tinggi lebih banyak pada pasien dengan biofilm (46,2\%), dibandingkan tanpa biofilm (44,4\%). Secara statistik tidak terdapat perbedaan bermakna pada skor Lund-Mackay antara pasien dengan biofilm dan tanpa biofilm $(\mathrm{p}=1,000)$. Kesimpulan: Tidak terdapat hubungan antara biofilm bakteri dengan derajat keparahan RSK berdasarkan skor Lund-Mackay.
\end{abstract}

Kata Kunci: Rinosinusitis kronis, biofilm bakteri, tube method, skor Lund-Mackay

\section{ABSTRACT}

Background: Chronic rhinosinusitis (CRS) is inflammation of the nose and paranasal sinuses with the symptoms duration more than 12 weeks. Many conditions have been linked to its pathogenesis such as bacterial and fungal infection, superantigens and biofilm. Many studies showed the presence of bacterial biofilms in patients with CRS. Bacterial biofilms can facilitate the resistance to antibiotics. Paranasal sinuses (PNS) CT scan is the method of choice for radiological diagnosis of CRS. Lund and Mackay has developed a scoring system based on the CT finding to assess the quantification of inflammatory process in PNS. Some research suggested that patients with bacterial biofilms have higher Lund-Mackay score pre-operatively. Purpose: To determine the role of bacterial biofilms to the severity of CRS according to Lund-Mackay score. Methods: This was a cross-sectional study with 48 CRS patient's sample. Nasal discharges were taken by swab in middle meatal using sterile cotton buds, followed by identification of bacteria and detection of bacterial biofilms using tube method. Lund-Mackay score was counted from coronal section of PNS CT Scan. Data was analyzed by Fisher's exact test. Results: Proportion of patients 
CRS with high Lund-Mackay score was more common in patient with biofilm (46.2\%) compared to patients without biofilm (44.4\%). Statistically, there was no significant difference of Lund-Mackay score between patient with biofilm and without biofilm $(p=1.00)$. Conclusion: There was no relationship between the bacterial biofilm with the severity of CRS according to Lund-Mackay score.

Keywords: Chronic rhinosinusitis, bacterial biofilm, tube method, Lund-Mackay scores

Alamat korespondensi: dr. Yolazenia, M. Biomed, Sp.T.H.T.K.L. Fakultas Kedokteran Universitas Riau. Jl. Diponegoro No.1, Pekanbaru. Email: yolazenia@lecturer.unri.ac.id.

\section{PENDAHULUAN}

Rinosinusitis kronis (RSK) adalah penyakit inflamasi mukosa hidung dan sinus paranasal yang berlangsung lebih dari 12 minggu. Pengobatan RSK masih belum dapat berjalan optimal disebabkan berbagai faktor seperti gen, lingkungan, infeksi, superantigen, dan biofilm. Rinosinusitis kronis tidak hanya memengaruhi kualitas hidup pasien, tetapi juga menyebabkan tingginya biaya kesehatan akibat kegagalan pengobatan. ${ }^{1}$

Rinosinusitis kronis merupakan salah satu keluhan medis paling umum ditemukan di Amerika Serikat, yaitu ada lebih dari 13 juta kunjungan dokter setiap tahun enganyang menghabiskan dana kesehatan sekitar 6 milyar dolar setiap . ${ }^{2}$ Prevalensi RSK di Amerika Serikat per tahun sekitar $13-16 \% .{ }^{1}$ Prevalensi rinosinusitis masih cukup tinggi di Indonesia. Insiden kasus baru rinosinusitis pada penderita dewasa yang datang ke Poliklinik Rinologi Departemen Telinga Hidung Tenggorok Bedah Kepala dan Leher (THT-KL) Rumah Sakit Dr. Cipto Mangunkusumo Jakarta pada tahun 2005 adalah 300 pasien (69\%). ${ }^{3}$ Insiden di Rumah Sakit Umum Pusat (RSUP) dr. M. Djamil Padang pada periode Oktober 2011 sampai September 2012 ditemukan 106 kasus baru RSK. $^{4}$

Patofisiologi dari RSK masih belum dapat dijelaskan secara pasti. Berbagai kondisi telah dikaitkan dengan patogenesis penyakit ini, seperti infeksi bakteri gram positif dan gram negatif, jamur, dan superantigen. Akhirakhir ini, telah dilakukan beberapa studi yang berhubungan dengan kemungkinan peran dari biofilm bakteri pada RSK yang sulit diobati. ${ }^{2,5-7}$
Biofilm adalah suatu struktur komunitas sel-sel bakteri yang ditutupi oleh matriks polimer yang dihasilkan sendiri dan menempel pada permukaan. ${ }^{5}$ Biofilm bakteri telah dikenal berperan penting dalam patogenesis berbagai infeksi pada manusia. Centers for Disease Control and Prevention (CDC) di Amerika Serikat memperkirakan sedikitnya $65 \%$ dari semua bakteri yang infeksius pada manusia melibatkan biofilm bakteri, dan hal ini berhubungan dengan kronisitas infeksi. ${ }^{6}$ Beberapa penelitian telah menunjukkan terdapatnya biofilm bakteri pada pasien dengan RSK. Prince et $\mathrm{al}^{2}$ menemukan 28,6\% dari pasien RSK dengan sekret mukopurulen mengandung biofilm bakteri. Singhal et $\mathrm{al}^{7}$ meneliti 39 pasien yang menjalani bedah sinus endoskopi fungsional (BSEF) untuk mendeteksi spesies bakteri pembentuk biofilm. Sebanyak 30 dari 39 pasien ditemukan mengandung kombinasi spesies bakteri berbeda, 60\% dari 30 biofilm ini merupakan biofilm polimikrobial, dan 70\% biofilm Staphylococcus aureus.

Peran bakteri sebagai penyebab RSK masih dalam perdebatan. Diketahui bahwa infeksi bakteri dan biofilm berkontribusi pada perkembangan RSK. Biofilm bakteri dapat menimbulkan resistensi pada antibiotick, sehingga penyakit sulit diobati. ${ }^{8}$ Metode untuk mengidentifikasi biofilm bakteri: Scanning Electron Microscopy (SEM), Transmission Electron Microscopy (TEM), Confocal Scanning Laser Microscopy (CSLM), Tissue Culture Plate (TCP) method, tube method dan congo red agar method. ${ }^{6,9-11}$

Computed-Tomography (CT) Scan sinus paranasal (SPN) merupakan pemeriksaan 
penunjang pilihan untuk diagnosis radiologi RSK. CT Scan SPN dapat mengevaluasi kavum nasi, kompleks osteomeatal, sinus paranasal, dan dapat memperlihatkan perluasan serta komplikasi penyakit. ${ }^{12,13}$ Lund dan Mackay telah mengembangkan suatu sistem berdasarkan skor dari CT Scan SPN untuk menilai kuantifikasi proses peradangan pada sinus paranasal sebelum pembedahan. Sistem ini dipillih oleh Task Force RSK dari American Academy of Otolaryngology - Head and Neck Surgery (AAO-HNS) untuk digunakan pada berbagai penelitian karena penilaiannya mudah dan jelas, sehingga dapat digunakan tanpa perlu pelatihan radiologi khusus.$^{14}$

Amodu et $a 1^{13}$ menunjukkan bahwa ada hubungan yang bermakna antara skor LundMackay dengan sekret pada hidung dan sumbatan hidung, tapi tidak dengan gejala RSK yang lain. Pokharel et $\mathrm{al}^{12}$ menemukan secara keseluruhan terdapat hubungan yang bermakna antara skor gejala dan skor radiologi. Lebih jauh Bhattacharyya ${ }^{15}$ menunjukkan bahwa inflamasi pada penderita RSK yang dibuktikan secara histopatologi, berkorelasi kuat dengan temuan CT Scan. Vaid et al ${ }^{16}$ menunjukkan bahwa pasien dengan biofilm bakteri memiliki skor gejala RSK yang lebih tinggi. Psaltis et a ${ }^{17}$ mendapatkan pasien dengan biofilm bakteri memiliki skor Lund-Mackay CT Scan SPN yang lebih tinggi pada saat pra operatif.

Skor Lund-Mackay pada CT Scan SPN dapat menggambarkan beratnya inflamasi dengan gejala dan kejadian biofilm bakteri. Tube method adalah suatu metode pemeriksaan sederhana untuk menilai biofilm bakteri secara kualitatif. ${ }^{9}$ Pemeriksaan biofilm bakteri menggunakan tube method ini relatif mudah, murah, dan mempunyai sensitivitas dan spesifisitas yang cukup baik. ${ }^{11}$ Berdasarkan hal tersebut, perlu dilakukan penelitian mengenai biofilm bakteri yang diperiksa secara tube method dan dihubungkan dengan derajat keparahan RSK berdasarkan skor Lund-Mackay CT Scan SPN. Publikasi mengenai biofilm bakteri pada penderita RSK di Indonesia masih terbatas, sehingga diharapkan dengan publikasi ini dapat menambah wawasan tentang teknik pemeriksaan biofilm bakteri pada penderita RSK serta dihubungkan dengan derajat keparahan penyakit berdasarkan skor LundMackay.

\section{METODE}

Penelitian ini merupakan penelitian cross-sectional untuk mengetahui hubungan biofilm bakteri dengan skor Lund-Mackay CT Scan SPN pada penderita rinosinusitis kronis. Penelitian telah mendapat ethical clearance dari Komite Etika Penelitian Fakultas Kedokteran Universitas Andalas. Penelitian dilakukan di Poliklinik Subbagian Rinologi THT-KL RSUP Dr. M. Djamil dan laboratorium Mikrobiologi Fakultas Kedokteran Universitas Andalas Padang pada bulan Juni 2015 sampai April 2016.

Besar sampel pada penelitian ini adalah 48 orang. Sampel diambil secara consecutive sampling dari pasien RSK yang memenuhi kriteria penerimaan dan penolakan, serta bersedia ikut dalam penelitian dengan mengisi lembar persetujuan (informed consent). Kriteria inklusi yaitu penderita RSK sesuai dengan kriteria European Position Paper on Rhinosinusitis and Nasal Polyps (EPOS) 2012 yang telah mendapat terapi medikamentosa optimal selama minimal 2 minggu, umur 1860 tahun, dan bersedia ikut dalam penelitian. Kriteria eksklusi adalah penderita RSK dengan tumor kavum nasi, dan dengan polip nasi stadium III bilateral.

Diagnosis RSK ditegakkan berdasarkan anamnesis, pemeriksaan fisik, dan nasoendoskopi di Poliklinik Telinga Hidung Tenggorok - Bedah Kepala Leher (THT-KL). Pengambilan sampel (sekret hidung) dilakukan menggunakan lidi kapas steril dengan panduan nasoendoskopi secara $s w a b$ pada meatus media, lalu dilakukan pemeriksaan biofilm menggunakan metode tabung (tube method). Pada pasien juga dilakukan pemeriksaan $C T$ 
Scan SPN tanpa kontras potongan aksial dan koronal irisan $3 \mathrm{~mm}$ soft tissue setting.

Hasil swab hidung pada lidi kapas ditanam pada lempeng agar darah dan dilakukan kultur dan identifikasi bakteri. Pemeriksaan biofilm menggunakan metode tabung (tube method). Sepuluh mililiter $(10 \mathrm{ml})$ media Trypticase soy broth dengan glukosa 1\% (TSBglu) diinokulasi dengan koloni bakteri hasil kultur dari swab hidung dan diinkubasi selama 24 jam pada suhu $37^{\circ} \mathrm{C}$. Tabung kemudian dicuci dengan Phosphat Buffer Saline (PBS) dan dikeringkan. Tabung kering ini lalu diwarnai dengan kristal violet $(0,1 \%)$. Sisa pewarnaan dibuang dan tabung dicuci dengan aquadest. Tabung kemudian dikeringkan dengan posisi terbalik dan dilihat adanya pembentukan biofilm bakteri. Pembentukan biofilm bakteri dikatakan positif jika terlihat lapisan berwarna keunguan menempel pada dinding dan dasar tabung.

Skor Lund-Mackay dinilai dari CTScan SPN tanpa kontras potongan koronal irisan 3 $\mathrm{mm}$ soft tissue setting pada slice-slice yang paling jelas menunjukkan kelima SPN dan KOM. Tiap sinus (maksila, etmoid anterior, etmoid posterior, sfenoid dan frontal) diberi skor antara 0 dan 2 (0: tidak ada abnormalitas; 1: opasifikasi parsial; 2: opasifikasi total). Kompleks osteomeatal diberi skor sebagai 0 (tidak ada obstruksi) atau 2 (obstruksi). Skor kemudian dijumlahkan secara terpisah kanan dan kiri serta secara total keseluruhan. Skor total yang dimungkinkan adalah 0-24, dan tiap sisi (kanan dan kiri) dinilai secara terpisah (012). Skor Lund-Mackay total dikategorikan sebagai tinggi atau rendah berdasarkan nilai median dari hasil yang didapatkan yaitu 10 . Skor Lund-Mackay dikategorikan sebagai rendah bila nilainya $\leq 10$, dan tinggi bila nilainya $>10$.

Data yang diperoleh dari pemeriksaan kemudian dilakukan pengolahan data dengan komputer program SPSS, serta disajikan dalam bentuk tabel dan grafik. Data dianalisis secara deskriptif dan untuk melihat hubungan biofilm bakteri dengan skor Lund-Mackay $C T$
Scan SPN dilakukan uji Fisher. Hasil analisis statistik dinyatakan bermakna bila didapatkan hasil $\mathrm{p}<0,05$.

\section{HASIL}

Didapati sampel penelitian sebanyak 48 orang pasien RSK, terdiri dari $28(58,3 \%)$ pasien RSK tanpa polip nasi dan $20(41,7 \%)$ pasien RSK dengan polip nasi. Karakteristik umum pasien pada penelitian didapatkan berjenis kelamin perempuan 26 orang $(54,2 \%)$ dan laki-laki 22 orang (45,8\%). Berdasarkan kelompok umur didapatkan pasien lebih banyak pada kelompok umur 41-60 tahun sebanyak 28 orang $(58,3 \%)$. Rerata umur pasien adalah $41,38 \pm 14,05$ tahun.

Pada gambar 1 dapat dilihat bahwa bakteri yang paling banyak ditemukan adalah Staphylococcus epidermidis yaitu pada 29 sampel $(60,4 \%)$.

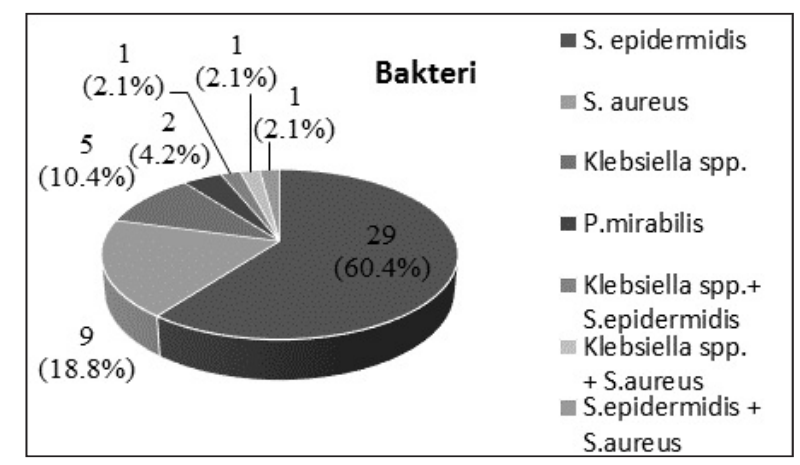

Gambar 1. Grafik distribusi spesies bakteri yang ditemukan pada pasien RSK $(n=48)$

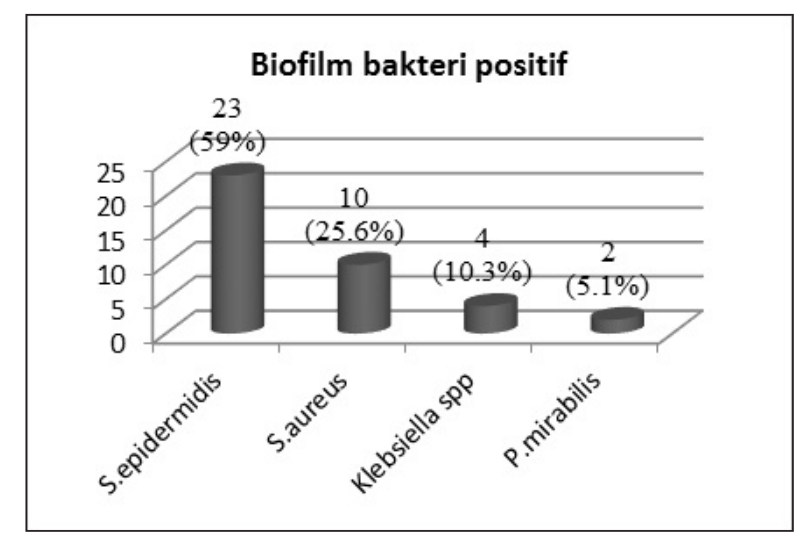

Gambar 2. Grafik distribusi frkuensi bakteri pembentuk biofilm pada pasien RSK $(n=39)$ 
Tabel 1. Hubungan Biofilm Bakteri dengan Skor Lund-Mackay pada Pasien RSK

\begin{tabular}{llllll}
\hline & \multicolumn{2}{c}{ Skor Lund-Mackay } & \multirow{2}{*}{ Total } & \multicolumn{2}{c}{ Nilai } \\
& \multicolumn{1}{c}{ Tinggi } & \multicolumn{2}{c}{ Rendah } & & P \\
\cline { 2 - 5 } & $18(46,2 \%)$ & $21(53,8 \%)$ & & $39(100 \%)$ & \\
Biofilm positif & $4(44,4 \%)$ & $5(55,6 \%)$ & $9(100 \%)$ & 1,00 \\
\hline
\end{tabular}

Biofilm bakteri positif ditemukan pada 39 sampel $(81,3 \%)$ dan biofilm negatif pada 9 sampel (18,8\%). Dari gambar 2 terlihat bahwa biofilm bakteri positif terbanyak ditemukan pada Staphylococcus epidermidis (59\%).

Skor Lund-Mackay yang tinggi ditemukan pada 23 orang pasien (47,9\%), sedangkan skor Lund-Mackay yang rendah ditemukan pada 25 orang $(52,1 \%)$. Skor Lund-Mackay rata-rata adalah $10,35 \pm 4,99$, nilai median 10 , dengan nilai minimum 2 dan nilai maksimum 21 .

Pada tabel 1 terlihat bahwa pada pasien dengan skor Lund-Mackay yang tinggi, sedikit lebih banyak ditemukan pada biofilm positif $(46,2 \%)$ dibandingkan dengan biofilm negatif $(44,4 \%)$. Secara statistik tidak terdapat perbedaan bermakna pada skor Lund-Mackay antara pasien dengan biofilm dan tanpa biofilm $(\mathrm{p}=1,000)$.

\section{DISKUSI}

Pada penelitian ini didapati pasien RSK berjenis kelamin perempuan 26 orang $(54,2 \%)$ lebih banyak dari pada laki-laki 22 orang $(45,8 \%)$. Hal ini hampir sama dengan penelitian Pokharel et al ${ }^{12}$ yang mendapatkan $63,2 \%$ pasien perempuan dan $36,8 \%$ pasien laki-laki. Sedangkan Amodu et al ${ }^{13}$ mendapatkan lakilaki (57\%) lebih banyak dibanding perempuan (43\%). Laki-laki lebih rentan mendapat RSK dapat dikarenakan faktor risiko merokok. Banyaknya insiden RSK ditemukan pada perempuan, dapat disebabkan perempuan lebih peduli untuk mendapatkan pelayanan kesehatan dibanding laki-laki. ${ }^{18}$

Pada penelitian ini didapati pasien lebih banyak pada kelompok umur 41-60 tahun sebanyak 28 orang $(58,3 \%)$ dengan umur rata-rata 41,38 $\pm 14,05$ tahun. Hal ini hampir sama dengan penelitian Amodu et a ${ }^{13}$ dengan rentang umur pasien sama dengan penelitian ini yaitu 18-60 tahun didapatkan umur ratarata 35,6 $6 \pm 11,42$. Meningkatnya prevalensi RSK seiring pertambahan usia dapat dijelaskan dengan terjadinya perubahan fungsi mukosiliar, penurunan frekuensi gerakan silia, dan kerusakan pada mikrotubulus sentral. ${ }^{19}$

Bakteri yang paling banyak ditemukan pada pasien adalah Staphylococcus epidermidis yaitu pada 29 sampel $(60,4 \%)$ dan ditambah 2 pasien dalam bentuk infeksi campuran yaitu 1 pasien dengan S. epidermidis + Klebsiella spp., 1 pasien dengan $S$. epidermidis + S. aureus. Hal ini hampir sama dengan penelitian Dlugaszewska et $\mathrm{a}^{20}$ di Polandia yang mendapatkan $S$. epidermidis sebagai mikroorganisme yang paling banyak ditemukan pada sampel pasien RSK, diikuti dengan $S$. aureus, bakteri gram negatif (E. coli, Klebsiella spp.) dan bakteri anaerob (S. saccharolyticus, Propionibacterium granulosum). Marcinkiewicz et al ${ }^{21}$ mendapatkan S. epidermidis pada 7 dari 10 $(70 \%)$ kasus RSK.

S. epidermidis adalah bakteri yang tergolong dalam kokus koagulase negatif. Bakteri ini biasanya hidup komensal yang mengkolonisasi kulit dan membran mukosa mamalia. Peran S. epidermidis atau bakteri kokus koagulase negatif lainnya pada patogenesis RSK masih belum jelas, sebab bakteri ini cenderung berkolonisasi pada kavum nasi dalam kondisi normal. ${ }^{20}$ Bagaimanapun, S. epidermidis terbukti merupakan penyebab paling umum dari bakterimia dan infeksi pada alat-alat medis, terutama pada pasien imunokompromais dan neonatus. ${ }^{22}$ Demikian juga peran $S$. epidermidis pada RSK telah 
ditunjukkan oleh beberapa peneliti. ${ }^{20,21}$ Bakteri koagulase negatif berperan pada proses infeksi melalui pembentukan bahan-bahan biokimia intra dan ekstraseluler seperti polisakarida dan substansi protein adhesive menghasilkan kolonisasi dan infeksi persisten. ${ }^{20}$ Berdasarkan hasil penelitian menunjukkan bahwa $S$. epidermidis merupakan bakteri yang paling banyak ditemukan. Bakteri ini bukan hanya merupakan patogen nosokomial utama yang berhubungan dengan infeksi alat-alat medis implan tapi, juga pada penderita RSK.

Staphylococcus aureus merupakan bakteri kedua terbanyak yang ditemukan pada penelitian ini sebagai penyebab RSK yaitu pada 9 pasien (18,8\%) ditambah 2 dalam bentuk infeksi campuran yaitu: 1 pasien dengan $S$. aureus + Klebsiella spp. dan 1 pasien dengan $S$. aureus + S. epidermidis. Hal ini sama dengan penelitian Dlugaszewska et $\mathrm{al}^{20}$ yang mendapatkan $S$. aureus sebagai bakteri kedua setelah $S$. epidermidis. Hal yang berbeda ditemukan pada beberapa penelitian lain. Zhang et $\mathrm{al}^{23}$ mendapatkan bakteri yang dominan pada pasien RSK adalah $S$. aureus diikuti dengan $P$. aeruginosa, $H$. influenzae, $S$. pneumoniae dan Serratia marcescens. Hal yang hampir sama didapatkan oleh Atay et $\mathrm{al}^{24}$ di mana $S$. aureus merupakan bakteri yang paling dominan pada pasien RSK (62,5\%).

Pada penelitian ini didapatkan 5 pasien dengan Klebsiella spp. $(10,4 \%)$ ditambah 2 pasien dengan infeksi campuran yaitu 1 pasien dengan Klebsiella spp. + S.epidermidis dan 1 pasien dengan Klebsiella spp.+ S.aureus, dan 2 pasien dengan Proteus mirabilis (4,2\%). Klebsiella spp. dan Proteus mirabilis merupakan bakteri gram negatif yang keberadaannya juga ditemukan sebagai patogen pada penderita RSK dengan frekuensi yang lebih sedikit. Vaid et al ${ }^{16}$ mendapatkan 1 pasien dengan Proteus dari 13 pasien dengan kultur positif. Dlugaszewska et $\mathrm{al}^{20}$ mendapatkan 1 pasien dengan hasil kultur Klebsiella spp. dari 30 pasien yang diperiksa.

Sampel untuk kultur bakteri pada penelitian ini adalah sekret hidung yang pengambilannya secara swab pada meatus media melalui kavum nasi, dengan kemungkinan adanya kontaminasi bakteri komensal dari kavum nasi. Selain itu, walaupun kami tidak memasukkan pasien polip nasi stadium III, untuk pasien polip nasi stadium II terkadang masih susah untuk mencapai meatus media, sehingga bisa terkontaminasi. Untuk meminimalisir kekurangan ini, swab dilakukan dengan panduan nasoendoskopi.

Hubungan antara RSK dengan biofilm pertama kali digambarkan oleh Perloff dan Palmer pada tahun 2004. ${ }^{25}$ Sejak itu sejumlah penelitian sudah dilakukan untuk menunjukkan peran biofilm bakteri ini pada RSK. Oleh karena perbedaan metode, angka biofilm yang dilaporkan bervariasi. ${ }^{21}$ Pada penelitian ini didapatkan frekuensi biofilm 81,3\%. Penemuan ini hampir sama dengan penelitian Atay et $\mathrm{al}^{24}$ yang mendapatkan $80 \%$ dari pasien RSK dengan biofilm. Beberapa peneliti lain menemukan angka yang sedikit lebih rendah, seperti penelitian Dlugaszewska et $\mathrm{al}^{20}$ dan Singhal et $\mathrm{al}^{7}$ yang masing-masing mendapatkan $76,7 \%$ dan $76,9 \%$ pasien RSK dengan biofilm bakteri. Penelitian-penelitian tersebut menggunakan metode SEM dan CSLM untuk mendeteksi biofilm.

Prince et $\mathrm{al}^{2}$ menggunakan metode modifikasi Calgary Biofilm Detection Assay mendapatkan angka persentase yang lebih sedikit yaitu 45 dari 157 pasien $(28,6 \%)$ menunjukkan pembentukan biofilm. Vaid et a ${ }^{16}$ mendapatkan 8 dari $13(61,53 \%)$ bakteri membentuk biofilm yang diperiksa dengan TCP. Singh et $\mathrm{al}^{26}$ menggunakan TCP, CRA, dan tube method mendapatkan biofilm bakteri pada 26 dari 50 (52\%) pasien RSK yang diperiksa.

Pada penelitian ini, pemeriksaan biofilm dilakukan menggunakan tube method. Tube method merupakan suatu pemeriksaan pembentukan biofilm secara kualitatif yang diperkenalkan oleh Christensen et al. ${ }^{9}$ Pemeriksaan biofilm bakteri menggunakan tube method ini mempuyai sensitivitas $73 \%$ dan spesifisitas $92,5 \%{ }^{11}$ Kekurangan metode ini 
adalah sulit membedakan isolat dengan biofilm lemah atau negatif, disebabkan variabilitas penilaian antar pengamat yang berbeda sehingga dapat terjadi kesalahan subyektif. ${ }^{10}$

Pembentukan biofilm dipengaruhi oleh berbagai faktor. Faktor-faktor yang berhubungan dengan pembentukan biofilm antara lain adalah umur, jenis kelamin, riwayat operasi sinus, riwayat penggunaan steroid dan hasil kultur yang positif. ${ }^{23}$ Pada penelitian ini kami tidak menemukan perbedaan yang bermakna antara umur dan jenis kelamin pada pasien RSK dengan biofilm dan tanpa biofilm.

Pada penelitian ini didapatkan biofilm bakteri positif terbanyak ditemukan pada Staphylococcus epidermidis (59\%), diikuti dengan Staphylococcus aureus (25,6\%), Klebsiella sp (10,3\%), dan Proteus mirabilis $(5,1 \%)$. Dlugaszewska et $\mathrm{al}^{20}$ mendapatkan 5 isolat sebagai pembentuk biofilm kuat pada pasien RSK yaitu 2 strain $S$. epidermidis, 2 strain E. coli dan 1 strain C. freundii. Marcinkiewicz et $\mathrm{al}^{21}$ juga mendapatkan $S$. epidermidis pada semua sampel RSK dengan biofilm positif. Tingginya prevalensi $S$. epidermidis pada RSK dengan pembentukan biofilm dapat dijelaskan dengan kolonisasi permanennya pada kavum nasi dan produksi slime yang masif, eksopolisakarida yang penting untuk penempelan $S$. epidermidis yang bersifat irreversible pada mukosa pasien dengan infeksi kronis. ${ }^{27}$

Staphylococcus aureus merupakan bakteri kedua terbanyak yang ditemukan membentuk biofilm pada penelitian ini. Hal ini berbeda dengan Singhal et $\mathrm{al}^{7}$ yang mendapatkan $S$. aureus merupakan bakteri yang paling umum membentuk biofilm. Tan et $\mathrm{al}^{28}$ mengidentifikasi S. aureus intraseluler pada $20 / 36(56 \%)$ pasien RSK. S. aureus intraseluler ini berhubungan dengan terdapatnya permukaan biofilm.

Sedangkan Prince et $\mathrm{al}^{2}$ mendapatkan Pseudomonas aeruginosa sebagai bakteri yang dominan membentuk biofilm pada pasien RSK. Pseudomonas aeruginosa tergolong ke dalam bakteri gram negatif. Pada penelitian ini tidak ditemukan $P$. aeruginosa, tetapi ditemukan bakteri gram negatif lain yaitu Klebsiella spp dan Proteus mirabilis yang membentuk biofilm dalam frekuensi yang lebih sedikit (10,3\% dan $5,1 \%)$.

Peran infeksi bakteri pada RSK masih belum jelas. Pendapat ini didukung dengan temuan tidak efektifnya terapi antibiotik pada kebanyakan kasus RSK. Dengan diidentifikasinya biofilm bakteri pada mukosa pasien RSK dengan polip maupun tanpa polip pada beberapa penelitian, menunjukkan bahwa bakteri memiliki peran yang lebih kompleks pada RSK. ${ }^{1,20}$

Pada penelitian ini didapatkan rata-rata skor Lund-Mackay adalah 10,35 $\pm 4,99$ dan median 10. Pokharel et al ${ }^{12}$ pada penelitian di Nepal mendapatkan rata-rata skor LundMackay pasien RSK yang hampir sama yaitu $11,3 \pm 5,24$ dan secara keseluruhan didapatkan hubungan yang bermakna antara skor gejala dan skor radiologi. Sedangkan Amodu et $\mathrm{al}^{13}$ di Nigeria mendapatkan rata-rata skor LundMackay lebih tinggi yaitu $16,78 \pm 3,76$, dengan nilai median 16. Lebih lanjut Amodu et al ${ }^{13}$ menunjukkan bahwa terdapat hubungan yang bermakna antara skor Lund-Mackay dengan sekret pada hidung dan sumbatan hidung tapi tidak dengan gejala RSK yang lain. Vaid et al ${ }^{16} \mathrm{di}$ India mendapatkan rata-rata skor LundMackay $15,87 \pm 7,45$. Bervariasinya distribusi skor Lund-Mackay ini bisa disebabkan karena perbedaan populasi penelitian. Di samping itu, pasien yang menjadi sampel penelitian ini sudah mendapat terapi medikamentosa optimal selama minimal 2 minggu sebelum dilakukan CT Scan SPN sehingga skor Lund-Mackay yang ditemukan cenderung lebih rendah.

Walaupun diagnosis RSK berdasarkan gejala dan durasinya, banyak klinisi yang menggunakan $C T$ Scan untuk menilai keparahan penyakit dan membantu untuk menentukan penatalaksanaannya. Derajat keparahan penyakit RSK dapat dinilai dengan menggunakan berbagai sistem. Lund-Mackay 
mengembangkan sistem untuk menilai derajat keparahan penyakit ini yang terdiri dari skor gejala, skor radiologi, skor endoskopi, dan skor operasi. Skor radiologi merupakan sistem yang paling sering digunakan dan dianjurkan oleh Task Force on Rhinosinusitis. ${ }^{14}$

Penelitian ini menunjukkan tidak terdapat perbedaan bermakna pada skor Lund-Mackay antara pasien dengan biofilm dan tanpa biofilm ( $p>0,05)$. Hal ini berbeda dengan penelitian yang dilakukan oleh Psaltis et $\mathrm{al}^{17}$ yang mendapatkan pasien dengan biofilm bakteri secara signifikan memiliki skor Lund-Mackay pra operatif yang lebih tinggi dibandingkan pasien dengan biofilm negatif. Biofilm bakteri dapat menyebabkan inflamasi persisten pada pasien RSK disebabkan sulitnya mengangkat biofilm tersebut yang menempel pada permukaan mukosa secara irreversible. ${ }^{17,20}$ Yan et al ${ }^{29}$ berpendapat pembentukan biofilm berhubungan dengan keparahan dari RSK.

Bagaimanapun, beberapa penelitian lain dengan metode pemeriksaan biofilm yang berbeda mendapatkan hasil yang sama dengan penelitian ini. Chen et $\mathrm{al}^{30}$ mendapatkan bahwa pada pasien dengan dan tanpa biofilm memiliki skor Lund-Mackay pra operatif yang hampir sama. Atay et $\mathrm{al}^{24}$ mendapatkan pasien dengan tingkat biofilm yang lebih tinggi berkorelasi dengan riwayat operasi BSEF sebelumnya tapi tidak berkorelasi dengan skor gejala pra operatif, skor Lund-Mackay CT Scan atau alergi. Yan et $\mathrm{a}^{29}$ mendapatkan pasien dengan biofilm cenderung memiliki skor Lund-Mackay yang lebih tinggi. Akan tetapi, perbedaan ini tidak signifikan secara statistik dan keberadaan biofilm berhubungan dengan skor endoskopi Lund-Kennedy dan skor sekret purulen. Selain dari skor radiologi, derajat keparahan RSK dapat dinilai dari skor gejala, skor endoskopi, dan skor operasi. ${ }^{14}$ Pada penelitian ini kami hanya menilai skor radiologi yaitu skor Lund-Mackay CT Scan SPN. Karena bervariasinya hasil penelitan, skor Lund-Mackay tinggi sepertinya tidak dapat dijadikan prediksi terdapatnya biofilm.
Beberapa hal berikut dapat menjadi penyebab tidak ditemukannya hubungan yang bermakna antara biofilm dengan skor LundMackay pada penelitian ini. Keberadaan biofilm tidak secara langsung sejalan dengan derajat keparahan inflamasi, sebab keparahan inflamasi pada pasien RSK disebabkan oleh berbagai macam faktor seperti faktor genetik, lingkungan, anatomi, dan faktor mikrobanya sendiri dimana disini termasuk spesies bakteri, superantigen dan biofilm. ${ }^{1,30}$ Perbedaan metode dan populasi pasien pada penelitian ini juga bisa menyebabkan hasil yang berbeda dengan penelitian lain. Pada penelitian ini untuk pemeriksaan biofilm menggunakan tube method yang bersifat kualitatif sehingga penilaiannya bersifat subjektif, dan pengambilan sampel secara swab pada meatus media memungkinkan terjadinya kontaminasi dengan kuman komensal dari kavum nasi. Penelitian selanjutnya sebaiknya mengambil sampel dari biopsi mukosa sinus sehingga dapat dipastikan bakteri yang dikultur bukan merupakan bakteri komensal/ kontaminasi dari kavum nasi dan melihat juga faktor-faktor lain yang mempengaruhi derajat keparahan RSK dan keberadaan biofilm.

Kesimpulan pada penelitian ini adalah walaupun tidak terdapat hubungan bermakna antara biofilm bakteri dengan skor LundMackay CT Scan SPN pada penderita RSK, penelitian ini memberikan wawasan tentang keberadaan biofilm bakteri pada penderita RSK yang dapat diperiksa menggunakan metode sederhana seperti tube method.

\section{DAFTAR PUSTAKA}

1. Patel ZM, Hwang PH. Nonpolypoid rhinosinusitis: pathogenesis, diagnosis, staging, and treatment. In: Johnson JT, Rosen CA, eds. Bailey's head \& neck surgery otolaryngology. Vol.1. Fifth edition. Philadelphia: Lippincott Williams \& Wilkins; 2014. P.535-47. 
2. Prince AA, Steiger JD, Khalid AN, Dogrhamji L, Reger C, Claire SE, et al. Prevalence of biofilm-forming bacteria in chronic rhinosinusitis. Am J Rhinol. 2008; 22:239-45.

3. Data poliklinik Rinologi THT-KL, RSUPN Dr. Cipto Mangunkusumo, Jakarta, 2005 (unpublished).

4. Data poliklinik Rinologi THT-KL, RSUP Dr. M. Djamil, Padang, 2012 (unpublished).

5. Palmer J. Bacterial biofilms in chronic rhinosinusitis. Annals of Otology. Rhinology \& Laryngology. 2006; 115(9)Suppl 196:359.

6. Tamashiro E, Antunes MB, Palmer JN, Cohen NA, Anselmo-Lima WT. Implication of bacterial biofilms in chronic rhinosinusitis. Braz J Infect Dis. 2009; 13:232-5.

7. Singhal D, Foreman A, Bardy JJ, Wormald PJ. Staphylococcus aureus biofilms: nemesis of endoscopic sinus surgery. Laryngoscope. 2011;121:1578-83.

8. Cain RB, Lal D. Update on the management of chronic rhinosinusitis. Infection and Drug Resistance. 2013;6:1-14.

9. Christensen GD, Simpson A, Bisno AL, Beachey EH. Adherence of slime-producing strains of Staphylococcus epidermidis to smooth surfaces. Infection and immunity. 1982; 37:318-26.

10. Sharvari S, Chitra P. Evaluation of different detection methods of biofilm formation in clinical isolates of staphylococci. Int J Pharm Bio Sci. 2012; 3:724-33.

11. Hassan A, Usman J, Kaleem F, Omair M, Khalid A, Iqbal M. Evaluation of different detection methods of biofilm formation in the clinical isolates. Braz J Infect Dis. 2011; 15:305-11.

12. Pokharel M, Karki S, Shrestha BL, Shrestha I, Amatya RC. Correlations between symptoms, nasal endoscopy, computed tomography and surgical findings in patients with chronic rhinosinusitis. Kathmandu Univ Med J. 2013; 11:201-5.
13. Amodu EJ, Fasunla AJ, Akano AO, Olusesi AD. Chronic rhinosinusitis: correlation of symptoms with computed tomography scan findings. Pan African Medical Journal. 2014; $18: 40$

14. Lund VJ, Kennedy DW. Staging for rhinosinustis. Otolaryngol Head Neck Surg. 1997; 117:S35-S40.

15. Bhattacharyya N. Relationship between mucosal inflammation, computed tomography, and symptomatology in chronic rhinosinusitis without polyposis. Annals of Otology. Rhinology \& Laryngology. 2008; 117:517-22.

16. Vaid L, Arya M, Gupta N, Singh PP, Saha R. Impact of biofilm on quality of life of rhinosinusitis patients after endoscopic sinus surgery. Clin Rhinol An Int J. 2012; 5:95-102.

17. Psaltis AJ, Weitzel EK, Ha KR, Wormald PJ. The effect of bacterial biofilms on postsinus surgical outcomes. Am J Rhinol. 2008; 22:1-6.

18. Beule AG. Epidemiology of chronic rhinosinusitis, selected risk factors, comorbidities, and economic burden. GMS Curr Topic in Otorhinol - HNS. 2015; 14:131.

19. Kim YS, Kim NH, Seong SY, Kim KR, Lee GB, Kim KS. Prevalence and risk factors of chronic rhinosinusitis in Korea. Am J Rhinol Allergy. 2011; 25:117-21.

20. Dlugaszewska J, Leszezynska M, Lenkowski M, Tatarska A, Pastusiak T, Szyfter W. The pathophysiological role of bacterial biofilms in chronic sinusitis. Eur Arch Otorhinolaryngol. 2015. Available from: http://www.springerlink.com.

21. Marcinkiewicz J, Strek P, Strus M, Glowacki R, Swiezy KZ, Gawda A, et al. Staphylococcus epidermidis and biofilm-associated chronic rhinosinusitis. A pilot study. Int J Exp Pathol. 2015; 96:378-86.

22. Fey PD, Olson ME. Current concepts in biofilm formation of Staphylococcus epidermidis. Futur Microbiol. 2010;5 :91733. 
23. Zhang Z, Kofonow JM, Finkelman BS, Doghramji L, Chiu AG, Kennedy DW,et al. Clinical factors associated with bacterial biofilm formation in chronic rhinosinusitis. Otolaryngol-HNS. 2011; 144:457-62.

24. Atay G, Yucel OT, Tatar I, Ozer S, Ogretmenoglu O, Celik HH, et al. Correlation of bacterial biofilm grade with clinical features in chronic rhinosinusitis. GMJ. 2013; 24:44-9.

25. Perloff JR, Palmer JN. Evidence of bacterial biofilms on frontal recess stents in patients with chronic rhinosinusitis. American Journal of Rhinology. 2004; 18:377-80.

26. Singh P, Mehta R, Agarwal S, Mishra P. Bacterial biofilm on the sinus mucosa of healthy subjects and patients with chronic rhinosinusitis (with or without nasal polyposis). J laryngol Otol. 2015; 129:46-9.

27. Nayak N, Satpathy G, Nag HL, Venkatesh P, Ramakrishnan S, Nag TC, et al. Slime production is essential for the adherence of Staphylococcus epidermidis in implantrelated infection. J Hosp Infect. 2011; 77:153-6.
28. Tan NCW, Foreman A, Jardeleza C, Douglas R, Tran H, Wormald PJ. The multiplicity of Staphylococcus aureus in chronic rhinosinusitis: correlating surface biofilm and intracellular residence. Laryngoscope. 2012; 122:1655-60.

29. Yan S, Bing Z, Cheng-shuo W, Qian H, Qi Z, Ye-hua $\mathrm{H}$, et al. Clinical and histopathologic features of biofilm-associated chronic rhinosinusitis with nasal polyps in Chinese patients. Chin Med J. 2012; 125:1104-9.

30. Chen HH, Liu X, Ni C, Lu YP, Xiong GY, $\mathrm{Lu} Y Y$, et al. Bacterial biofilms in chronic rhinosinusitis and their relationship with inflammation severity. Auris Nasus Larynx. 2012; 39:169-74. 